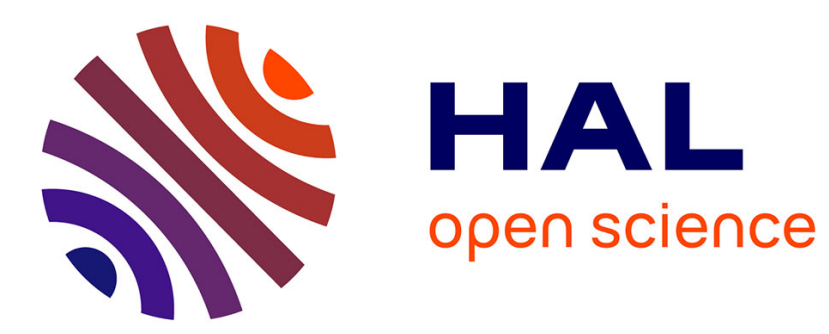

\title{
Champagne and Metal Flowers: Who is Invited to the Wind Generation Party in France?
}

Céline Burger, François Mancebo

\section{To cite this version:}

Céline Burger, François Mancebo. Champagne and Metal Flowers: Who is Invited to the Wind Generation Party in France?. Renewable Energy Governance, 2013, 10.1007/978-1-4471-5595-9_13 . hal-02157970

\author{
HAL Id: hal-02157970 \\ https://hal.science/hal-02157970
}

Submitted on 20 Jun 2019

HAL is a multi-disciplinary open access archive for the deposit and dissemination of scientific research documents, whether they are published or not. The documents may come from teaching and research institutions in France or abroad, or from public or private research centers.
L'archive ouverte pluridisciplinaire HAL, est destinée au dépôt et à la diffusion de documents scientifiques de niveau recherche, publiés ou non, émanant des établissements d'enseignement et de recherche français ou étrangers, des laboratoires publics ou privés. 


\title{
Champagne and Metal Flowers: Who is Invited to the Wind Generation Party in France?
}

\author{
Céline Burger and François Mancebo
}

\begin{abstract}
Sustainability has gradually become fundamental to the regional planning and decision-making process of French local governments. Local authorities are supposed to incorporate sustainability into their mode of governance. They do it, formally, but, the very idea of sustainable development implies a breakdown of the systems of reference for public action, and of individual and collective practices. So combining sustainability with preexisting governance uses is all but evident, as it appears with wind power plant development. In the ChampagneArdenne Region, local authorities are caught in the cross fire among developers, farmers, landowners, environmental activists, without any tool to help decisionmaking.
\end{abstract}

\section{Introduction}

When discussing renewable energy development everybody implicitly presupposes a functioning local governance and sustainable policies, a type of "government of compromise" (Taiclet 2007). François Hollande, during his recent October 29, 2012 speech specified that the energy transition issues will now placed under the responsibility of local authorities (mainly communes and inter-municipal organizations) within the new decentralization bill (Gaudin 2002). However, in Champagne-Ardennes, as in other French regions, policy coordination between local authorities is rather poor: hence there tends to be haphazard local governance actions (Pasquier et al. 2007). For example, in the process of land acquisition for

C. Burger $(\bowtie) \cdot$ F. Mancebo

Laboratory EA 2076 HABITER, 57 rue Pierre Taittinger 51096 Reims Cedex, France

e-mail: celine.burger@univ-reims.fr

F. Mancebo

e-mail: francois.mancebo@univ-reims.fr 
wind farm implantation programs, the decisions made by local authorities are directly and almost uniquely dependent on the immediate foreseeable financial gains, to the municipality hosting wind farms.

Champagne-Ardennes, the study site, was the first French region undertaking the production of wind power with an installed capacity of $838 \mathrm{MW}$ in $2011,21 \%$ more than in 2010 and $130 \%$ more than in 2009. The regional policy and political will proved decisive in this evolution (Le Gales 2006). But, on the other hand, Champagne-Ardenne region is also the only region in France in demographic decline, so the local authorities want to develop activities which attract people. Moreover, it faces the competition and attractiveness of very large urban areas of the Paris region -Ile-de-France- and of Alsace with Strasbourg. Thus, ChampagneArdennes suffers from a poor self regional brand image, despite its rich history. Nowadays, the perception of the region by its inhabitants is not good at all, because the territory has gone through lots of economic crises which have not helped people to build a link with their living territories, much people have lost their job.

Is it possible that wind farms installations generate a positive or negative impact on this perception? Could wind farms contribute to a "repopulation" of this region? At least, could the process of RE implementation itself-with its conflicts and its pitfalls-tell us something about the social and political dynamics that entails this negative perception?

These are the questions this chapter addresses, and which includes an inventory of regional information and local actions concerning wind power plants, followed by the analysis of both public and private local actor's interviews as well as antior pro-local news articles. The interviewees that I took included citizens directly concerned by wind farms (neighbors, farmers, etc.), local authorities and wind farms developers. Considering that local decision-making about the positioning of wind farms impacts concerns mainly local identity and territorial construction, this raises issues of local governance and the articulation of decision-making with search of sustainability.

\section{Promoting Renewable Energies Production in Champagne Ardenne: Mode of Land Acquisition and Participatory Governance}

Wind farms construction requires massive investments, as any industrial branch, and involves many stakeholders. Wind power market is therefore severely constrained by laws and regulations. Though financial issues strongly influence local stakeholder's choice to install wind power units, the economic benefits are definitely not shared among the household concerned by the wind projects (reasons will follow). On the other hand, the situation generates important conflicts at a local scale; that local authorities usually try to handle with participatory governance procedures (Ost 2004). 


\subsection{Which Strategies for Wind Farm Developers?}

In France, the installation cost of a wind turbine of $2.5 \mathrm{MW}$ is around 3 millions $€-75 \%$ of this sum concerns construction, $5 \%$ the development cost (impact studies), and the remaining $20 \%$ the earthworks, etc. This large cost makes it almost impossible for an individual, a household, or even a small village to undertake by themselves the installation of a wind turbine. Therefore, it is necessary that developers, with their investment capital, are involved in the wind farm development.

However, there are big differences among the developers: they don't share the same objectives and practices. Most of them are, at the same time, both developers and operators of wind farms, such as Ostwind or Enel Green Power. They handle the construction, the operation, and the maintenance of the equipment. This type of developer-operator is very active in Champagne-Ardenne. Those developers put big pressure on local authorities to foster new projects. However, it must be the local authorities who should control the decision making with process of participation and negotiation with all actors (Mancebo 2007b).

On average, a wind farm needs 15 years of exploitation to be profitable. As a result, some companies-Ostwind for example-keeps operating a number of their wind turbines in order to ensure stable financial resources in the long run, while the other companies sell to release cash so that they can reinvest. The new owner of a wind farm, usually outsources the operating part to a subcontractor, they are financial investors. The benefit to the new owner is in the differential between the operating costs and the income achieved from selling the produced electricity to the grid.

Often, the operator commissioned by the new owner is the original developeroperator who constructed the plant: it is a win-win deal with economies of scale for both partners. This system allows the developer/operator to charge operating fees to the investor, who-in the reality - might be a branch of the same company. These fees are a financial input, usually used to buy back the installations previously sold, when they become profitable. Besides, these developers/operators have strong ties and partnership with wind turbines manufacturers, like Repower, Enercom, or Vestas, and which are responsible for the installation of wind turbines on the selected sites.

The manufacturers associate the installation of wind turbines with maintenance contracts on their name, for the next 10 or 15 years. In case of underwriting this type of contracts, the maintenance is provided by the manufacturer during the first years of the operation. Therefore, some wind turbine manufacturers tend to become developers too as economic difficulties recently appeared in the wind turbine industry: therefore, they become developers/manufacturers aiming at a growth management strategy.

This happened with Gamesa group. This Spanish manufacturer has created a development branch. This branch of the company is in charge of the wind farm development, which wind farm will sold before begins operation. These wind 
farms are often sold by Gamesa through Wind Prospect, a wind farms broker for big companies like IKEA. ${ }^{1}$ Such a configuration assures the manufacturers that their wind turbines will be installed on upcoming wind farms once the building permit is obtained. There is a double interest here: If finally the developer/manufacturer is mandated to operate the wind farm, he receives payment for the exploitation of the farm and farm was created with the specific group turbines.

In the latter category of developers, design and technical consultants engineering offices can be called "developers/engineering offices": they got involved only recently in wind power development. These developers only manage the wind farms during the construction phase and their expertise usually doesn't enable them to go beyond this phase. An engineering office is supposed to deliver studies and reports for the companies that commission them. Developers/engineering offices can though undertake studies by themselves when they identify a site that is suitable for a wind development. Once these studies are done and if they prove positive, they sell their report either with the building permit granted or ready to be submitted to manufacturers or local authorities.

The business is profitable: usually, the price for a report with the building permit granted is about $250,000 € / \mathrm{MW}$ if the wind farm is well located, and $100,000 € / \mathrm{MW}$ if the location is less attractive. The benefits depend on many parameters, such cost of studies, cost of turbines, interest tax, and of course the production of farms which depend of physical aspect (numbers of wind hours, wind capacity, etc.). Nowadays, the reports without the building permit are naturally considerably less interesting because the risk for the buyer is not to be granted the permit afterwards.

There are several steps that precede the erection of a wind farm: the site choice, the feasibility study, the land acquisition, the constitution of the impact study, and the submission for the building permit. Purchasing (or renting) the land is the most delicate undertaking. It is commonly called by the developers in France, sécurisation du foncier (securing land use). This terminology makes sense: this is when the first confrontations between the different stakeholders take place. The conflicts that initiate at this phase of the project tend to intensify later, as public stakeholders come into the picture as supervisors (Torre et al. 2006). Short-term interests and personal or financial bias should not impact the decision-making process, neither should allow political shifts after election... but they usually do (Brunel 2010).

In the field of heritage development, many studies show that initiatives are frequently blocked when funders and public authorities do not coordinate their decision-making: they have trouble in imposing decisions to all the stakeholders (Cettolo et al. 2002): Paradoxically, when installing wind turbines, particular interests (often totally disconnected of the real issues of wind farms, such as to step up production of renewable energy to conform with European agreements, of renewable energy production), have a disproportionate impact on decision-making

\footnotetext{
1 IKEA owns wind farms to produce approximately the electricity equivalent consumed by IKEA group.
} 
(Mormont 2001). Indeed, wind farms usually settle in rural locations, therefore the communes that are concerned by wind projects often amount to less than 1,000 inhabitants. In such small populations, intense political rivalries, land use, and neighborhood conflicts between individuals or microscale social groups and families and/or vendettas, frequently affect decision-making process (Hirschman 1986).

Elected officials are commonly directly concerned by the projects, either as beneficiaries (when they rent their land to developers, for example), or negatively (when they are, for example, neighbors of wind turbines and have to support the, supposed, noise and view nuisance, or the impairment of their properties value). NIMBYs conflicts, fuelled by ancient grievances, often annihilate the efforts to implement wind generators, and the introduction of sustainable policy (Mancebo 2011).

Within all this development of "sustainable projects", as soon as a site is identified as potentially adequate for hosting a wind farm, the relations between wind developers routinely enter a phase of conflicts. Routinely, their relations are rather fraternal, as wind developers are all members of the Syndicat des Energies Renouvelables (SER-Renewable Energies Board), ${ }^{2}$ and are united particularly when they deal with the initiating departments. Relations turn confrontational on the spot, when developers rush to gain permits for the same site. To arbitrate potential conflicts among actors, a charte de l'éolien (chart for the wind industry) has been established. It consists of a code of good conduct that has been ratified by all members of the SER. Which means this is not a contractual document, and, as a consequence, some developers decide not to respect this ethical code, even if they are members of the SER.

According to French wind industry's professionals, ${ }^{3}$ it is the foreign companies that do not follow the unwritten code that says: "contact the mayors before the landowners." When they identify a potential plot to host a turbine, they meet directly the landowners, without necessarily contacting the mayor beforehand. For example, this practice not offends in Germany, where the practices are different. But, in France, French developers consider that this introduces a bias against them. Thus, more and more French companies adopt the same behavior.

\subsection{Respecting the Protocol for Land Acquisition}

The protocol for land acquisition allows the basis of the negotiation phase. It encompasses the successive steps of wind farm projects, defines everyone's obligations, and proposes a set of contract models (lease, extract of the cadastral

\footnotetext{
2 SER is the spokesman of the wind business in France toward public authorities and media. Its creation is due to the French government who focus on wind power industry to reach the objective of the law Grenelle II de l'environnement: to produce $23 \%$ of its energy out of renewable sources.

${ }^{3}$ Comment from fieldwork among project developer of wind in second quarter of 2012.
} 
map, lease of construction). It can also be considered as a reference document for good practices to install a wind farm.

As soon as a site is identified by developers, developers get in contact with the mayor of the municipalities concerned by the project. Identifying a site is the preliminary step and the feasibility studies are often conducted in-house by the development companies themselves. The principal criteria to define a site as suitable are: (a) available space and (b) environmental sensitivity. Getting in touch with the mayors is often made by phone. Developers present themselves, ask if the local community is interested in a wind project and whether they have already been contacted by another developer. A few years ago, if the mayor was already in touch with another developer, it was an established (though unwritten rule) that he should stop soliciting. Now, things are quite different: potential sites are becoming fewer and rarer, which induces strong competition among companies and developers outbid each other.

Nowadays, the cost for the land renting increases as there is more competition among the many developers: for example, it is now up to 5,000 €/MW in Champagne-Ardenne instead of 2,000 €/MW 2 years ago.

Once the mayor is convinced that the wind farm would be beneficial for the community, he usually acts in two different ways: either, he convenes the city council and provokes a debate without presenting his own choice, he then follows the council decision; or the developer he has chosen is directly invited to present his project during a normal city council session.

Some foreign companies which are not familiar with this way of business doing, short-circuit the mayors and get directly in touch with the landowners of the potential sites. These landowners are very easy to find, since the cadastre 4 of every French commune is on the Internet. It lists each lot and parcel with owners' names and addresses.

In the Mont des quatres Faux project in Champagne-Ardenne, the developer Winvision proceeded this way, contacting the landowners before the local authority. During the public inquiry for a wind farm installment, Denis Rousseaux - the mayor of the commune of La Neuville en Tourne à Fay-exposed in an interview that the developers began contacting the landowners and started trying to coax them. As a local elected politician, he felt at odds with such actions. Indeed, local elected politicians are in a precarious position: being against a wind farm project while landowners have given their approval, which might mean they lose votes and having trouble with the local population. But accepting the farm might create conflict with other local groups in the future who will be disturbed by the visual or noise impact of the farm.

For example, the Mont des quatres Faux project involves 47 turbines and expands more than $200 \mathrm{~m}$ height. The turbines are offshore models which are installed onshore! This means this is a huge construction work planned to last for

\footnotetext{
${ }^{4}$ A cadastre is a public record legal survey of the value, extent and ownership of land for taxation or administrative purposes.
} 
the future 3 years. Winvision always launch this type of project use the offshore turbines, like the Company did in Estinnes (Belgium).

At the same time the Company Winvision contacts the landowners and developers to ensure land security of the parcel. As we have seen previously, a potential area is previously defined for the project. The first identification phase is not very precise (to avoid great expenses). This potential area is therefore much larger than the area where the turbines will be actually positioned. Developers' work consists, at this point, in securing the land by having a lease agreement signed by all the concerned owners and renters.

The term "land security" makes perfect sense, when considering that developers voluntarily extend the area beyond their real needs, in order to ensure that no competitor will come near, thus strengthening their territorial arrangement. Among, the landowners who sign the promise to lease, some never will see any turbine on their fields. So that, when comes the time to announce who will have (or not) wind turbines in their property, the time for conflicts also comes along. Animosities arise between those who have turbines and those who have not, resulting in opposition movements against the installation.

Beyond all the justifications, it is usually the frustration that fosters the opposition movements (Hirshman 1970). The choice of the plots that will be hosting wind turbines is determined before submitting the application for a building permit. This choice can change thirty times a year, depending on the environmental impact studies. The environmental impact studies take 2 years, on average, sometimes more - up to 6 years - which means that promises to lease maintained for many years (for the land security), may become null all of a sudden, ensuing in big financial loss for the unlucky leasers.

At this stage, the policies of developers to avoid frustration are different and depend on the company. Some companies do not consider the promises of lease as engagements, thus they do not propose any compensations to the landowners. Others propose right the way agreements, passage agreements, overhang agreements, or installation of delivery substations (one for five turbines) to the landowners that do not have turbines on their fields: so they will receive a rent that will reduce their loss.

Other companies, finally, prefer to develop a general system of equalization payment to the landowners called ZDE (Zone de Développement Eolien-Wind power Development Area), where all the landowners inside the securing area ZDE receive a rent in direct proportion to the size of their lot, whether they have turbines or not. ZDE was formalized and generalized by the law Grenelle II de l'environnement. The municipalities usually establish ZDE where they want to allow the installation of wind farms. In order to respect these ZDE wind power development areas and under the article 10 of the law $n^{\circ} 2000-108$ about the modernization and development of the public service of the supply of electricity (modified by the law $n^{\circ} 2005-781$ defining French energy policy), only the wind turbines built in ZDE areas may benefit from the obligation imposed to EDF (Electricité de France-French national power operator) to buy the electricity they produce. 
In fact, the tariffs were very high and regulated to be fixed at the national level, which meant a comfortable and constant source of revenues for the wind power operators. Since July 13th 2007, only the electricity produced within ZDE are included and the tariffs have been re-estimated regularly to be closer to the energy market realities: for wind power onshore the price is $0.082 € / \mathrm{kWh}$ linked to the inflation rate during the ten first years of production. It then varies between 0.028 and $0.082 € / \mathrm{kWh}$ during the next 5 years depending on the location of the production site.

A wind farm owner or operator who installs his turbines outside a ZDE cannot ask for the green energy-purchasing obligation by EDF under the advantageous conditions fixed by the CSPE (Contribution au Service Public de l'ElectricitéContribution to the electricity public services). Connecting a wind turbine to a power network, outside a ZDE, and without a responsible entity for electricity purchasing, has become illegal. This law was repealed the 12th March 2013.

Once the competitive procedure is launched by the municipality, the choice of the developer is mainly based on the renting price he is ready to pay for the land and the financial investment he is ready to make for the thriving of the municipality. Therefore, the contract award decision depends heavily on pure financial issues as will be discussed in the next section. These issues usually result in another type of conflict, following those evoked before (choice of the turbines implantation sites, and promises of lease) but of a completely different type.

\section{Interesting Financial Issues}

Green energy development is encouraged by financial incentives like the feed-in tariff (see above). In France, the wind power market is doing well. Professionals in the wind power sector-especially developers-bring with them strong financial arguments when they want to convince municipalities, tenants, or landowners to accept wind farms on their land.

\subsection{The Profit Motive for the Municipalities (There is Good Money Here, but Whose Pocket is it Going to Go into?)}

The wind farms are usually located in rural areas. In order to be allowed to be installed, a wind farm must be located at least $500 \mathrm{~m}$ away from houses. Within the farm, there must be at least a distance $800 \mathrm{~m}$ between each turbine. Considering that a wind farm must have at least 5 turbines, the minimum area covered by a wind farm is about $2.132 \mathrm{~km}^{2}$. Furthermore, for the production to be optimized the wind must circulate regularly in the area. Because of these restrictions, it is almost impossible to install wind farms in urban environments. In ChampagneArdenne a lot of rural communes can provide optimal sites for wind farms. 
These, are small municipalities with around 300 inhabitants. Since the building and installation of a wind turbine cost is around three million euros, they cannot develop farms. Thus, when a mayor is prone to creating a wind farm, he absolutely needs developers' assistance and their financial strength. Developers make a financial commitment to the communes where they install wind farms. Apart from the rent received after the wind farm installation and the royalties received to accept the wind farm, this financial commitment may take two other forms:

- Specific endowment funds to municipalities supporting a project development. Though this is a legal provision, this type of payment raises a problem: If the project doesn't become a reality, the company (developer or operator) does not have to hold this financial commitment.

- The sponsorship through the contribution to an association promoting wind energy (for example 5,000 euros during 5 years). The wind energy's developers use more and more this possibility. Within the farm project called $\ll$ Mont des 4 faux $\gg$, the developer Winvision proceeded according to this very exact way.

Due to the financial support provided to the commune, developers hope to influence the local decision-making, fostering a positive bias toward their projects. The installation of a wind farm in a commune usually generates debates and opposition among the population: it may easily become a major political issue. And it is a long way from the blueprint to its realization: once local authorities give their approval for the implementation of a wind farm project, 26 public services have to be consulted before the building permit is delivered. It does not always work out, which usually ends in a backlash against the mayor in the next local elections.

Furthermore, in the Region Champagne-Ardenne, mayors are usually landowners and farmers, and so are the members of the municipal council. They are directly interested in the installation of wind turbines on their properties. They mostly judge the pros and cons of the project, which sparks all kind of reactions and concerns between opponents to the project and the municipal council during the public inquiry.

Statements in the local press usually exacerbate the conflicts. For example, in April 1, 2011 L'Union -the Champagne-Ardenne favorite local daily newspaperwrote on its first page: "Non aux fleurs en feraille?" (No to the metallic flowers). Then, on November 18 2011, an article supported the claims of the «Association de sauvegarde des paysages de la vallée de la Coole» (Valley of Coole landscape preservation association) against wind farms. On November 22nd 2011, the newspaper published the answer of GAMESA — the developer having undertaken the project in the Vallée de la Coole-presenting the goals of the project: which implies a production that optimizes the potential of all the turbines.

Recently, there has been an additional reason that makes the wind farms projects rather difficult to realize: the reform of the tax system, stipulating a TPUTaxe Professionnelle Unique (unique business tax) within each intercommunality. ${ }^{5}$

\footnotetext{
${ }^{5}$ It is a group of commune. You can enter in intercommunality with other commune which implies the sharing of power to many competences.
} 
This means that each and every commune counting less than 5,000 inhabitants has to be part of an intercommunality by 2013, and that the wind farm tax will be shared between the different municipalities of the intercommunality according to their population or surface. The consequence is that every commune concerned wants the wind turbines to be installed on different sites and different communes of the intercommunality; the idea being to spread the nuisances around since profits are shared.

Concluding, the wind turbines' placement cannot be made according to the sole desire of the mayors or the administrative limits of the communes. And wind turbines location is a real bottleneck for the installation of wind farms, since so many conflicting parameters which have to be considered both on the technical and on the human level. The local authorities love to present their arguments (use by person who is in favor of wind energy) from the point of view of the economic interests. That is why, on April 10th 2010, the mayor of the commune of Coole announced in L'Union that he will use wind farm's economic spinoffs (rent, subsidies, etc.) to bury all electricity lines in the village. A project that, according to him, "costs a lot".

The development of wind power is a real financial support for rural municipalities counting a few hundred inhabitants that cannot cope with some vital works with the small budget they have. The financial argument is also crucial to obtain a positive decision from the Prefect, the final, and only real decision maker.

In the commune of Epine aux Bois, the construction permit for Wolkswind Company's wind farm was delivered by the Prefect, who chose not to consider the unfavorable opinion expressed by the concerned local authorities and the public enquiry commissioner. And this is why the local authorities usually prefer to conciliate with developers in order to maximize the advantages they can obtain from the developers, rather than to adopt a passive attitude or to refuse the project, which can end in being forced to accept it finally but with less benefits; or, worse, to endure the nuisance of a wind farm installed in a neighbor commune without having any advantages.

The local authority position is ambiguous; they are rather "facilitators" than real decision-makers. Still, they are directly impacted by the economic dimension of the project, positively or negatively.

\subsection{No Redistribution, Big Frustration}

The landowners and the operators are the most important beneficiaries out of the installation of wind farms, whether they are involved, or not in the project. In Champagne-Ardenne the first wind farm was built in the department of La Marne in 2002 as a private initiative of a local farmer, Mr Huet. In fact, wind potential in Champagne-Ardenne is rather poor. So, in the beginning, nobody believed in this project. Developers were not interested. But Mr. Huet insisted and finally succeeded in building a wind farm. 
Because of this first success, wind farms started developing swiftly in Champagne-Ardenne. Today, more than $95 \%$ of the wind farms in Champagne-Ardenne are created by developers, while the farmers who were the pioneers finally sold their turbines to private providers; like Mr Huet, who sold his wind farm to Eole Generation in 2007. This company extended the surface of the farm and changed its name into Mont de l'Arbre. Mr Prince, another farmer-now a shareholder in the wind farm Chapelle Vallon,- - created the second wind farm of the region, in the department of Aube. He explains that his sudden interest in wind power was due to the evolution of the European CAP (Common Agricultural Policy).

In fact, French farmers, after the EU enlargement, thought that the CAP would be threatened and that the subsidies will diminish greatly. Thus, compensatory indemnities on their classical framing activity could turn inadequate to ensure the agro-profitability of their establishments. Green power development, like bio-fuels and wind power, appeared as a good way to diversify the activities of some farmers. Besides, the regional council of Champagne-Ardenne, provides a big support to the Chamber of Agriculture, which promotes wind power industry as a way of diversifying farmers activities without losing agricultural land (unlike with what happens with ground photovoltaic energy for example). In such a context, wind farms are emerging as an important issue for Champagne-Ardenne's economy.

At the same time there are more and more norms to respect when installing a wind farm (ZDE, ranking ICPE, minimum size, etc.). It results from this burgeoning regulatory framework that the financial cost to create a wind farm increases steadily. Thus, wind power branch is now an industrial sector, where only big companies can play.

The rent to the landowners and to the operators is around 3,000 €/MW, but when the farmers bring their contract to the Chambre d'agriculture, they voluntarily hide the rent. In theory, the rent is distributed for $1 / 3$ to the operators, and $2 / 3$ to the landowners. In fact, as observed with Enel Green Power Company, the distribution is equal between operators and landowners, sometimes even more for the operator. The lease is usually signed only after important negotiations between operators, developers, and landowners. During the construction work, there is a special compensation, since transporters of wind turbines cannot only drive in the edge of the construction area but have to pass through it. Thus, the operator receives an agricultural compensation for the damages caused: compensation for the rights of way, compensation for things such a ruts in the fields from the large transporting lorries.

Once the wind turbines are installed, a lot of money flows between the operators and the farmers. Oppositions against wind farms are often due to the fact that the wind power sector is a hyper lucrative sector but the benefits only go to the owners and the developers, with nothing left for the inhabitants. In order to avoid problems, some developers pay all the owners and operators of the ZDE. But this has apparently proved not enough to calm down the tensions. In the Lorraine Region the pooling the wind farm's rent is almost systematic. In Champagne-Ardenne this way of proceeding does not work, most farmers have a capitalist attitude more individualistic for land management and less practiced sharing action of benefits. 
Most landowner farmers in Champagne-Ardenne have big agricultural holdings in open field.

Paradoxically, in Champagne-Ardenne the opponents of wind farm are still few in number in comparison to regions like Picardie where the opposition is systematic. The "Association de Sauvegarde des paysages de la vallée de la Coole" is one of the two associations to be opposing to wind farms installation in Champagne-Ardenne, this association can be considered as structural stakeholders group for the social relation (Chia et al. 2008). The members of this Association consider that financial gains are the only reason for wind power installation. For the people who oppose wind farm installation, wind energy exploitation is responsible for the deregularization of the land.

The price for renting a land with a wind turbines is 330 times higher what the exploitation of a same agricultural land can produce with traditional activity (land cultivation) according to the leader of the movement, Mrs. Robert: «for a very small parcel of a land, it is too much $\gg, \ll$ an agricultural land is made for feeding people, the size of a French department disappears every 10 years because of city's extension, many hectares of agricultural lands disappear due to the installation of wind turbines $\gg .^{6}$

Mrs. Robert also argues that the mayor of Cernon-the commune where she lives, in the Marne department (in French "département")—-supports the wind power project only for financial reasons: «during his commune's meetings, he supported this project because it brings money; it's what he always says in these meetings $\gg ; ~ \ll$ nowadays mayors are keen for turbines because they want to invest in other projects and they need money $\gg$.

Still, the opponents argue that «small rural towns will become ghost towns, without anyone but with new schools and city hall $\gg$ : Naturally, the money generated by wind farms could induce the creation of new services in rural areas, therefore attracting people, but the members of these associations don't agree with this idea: according to them, wind turbines fuel neighbors conflicts, and the opponents feel misunderstood and rejected by the other inhabitants. They also think that developers «win money with wind turbines who make embarrassment for people $\gg$, and are worried about the value of their land: «what if we will not be able to sell our houses because of that (the wind turbines) $\gg$; «you have worked all your life and someone puts that in front of your house $\gg$.

\section{Discussing the Whole Situation}

A territoriale governance considered territory as an area of collective project (Lagagnier 2002) governed by rules allowing concerted public action (Le Gales 1995). However, this type of governance has limits, as the wind energy project, the

${ }^{6}$ Interview with Mrs. Robert, the 17th July 2012 at Cernon. 
multitude of stakeholders, and the difference of their interest, compromised power regulator of local authorities and the decision-making is affected. To solve the problem we can use the participatory governance (Mancebo 2007a). But, regional distinctiveness and the individuality compromised the utilization of participatory governance, as in Champagne-Ardenne where the individualities are strong. These observations, asked the question of what type of governance can we used, to reconcile different challenges and posed the question about values and principle compatible with sustainabilities (Buclet 2011).

In France, and through the green energy-purchasing obligation of EDF, the government subsidizes de facto wind power industry. This turns wind industry into a very profitable business. Even as the purchase tariff constantly decreases, there is always the same huge number of wind power companies and developers who try to enter the market. This purely financial profitability is an issue very frequently criticized by wind power opponents. What is the real link among frustration, envy, and opposition? If the wind power industry was not such a profitable business, would it ever have so many opponents? On the contrary, if someday the wind game becomes much less profitable; would the developers disengage from the wind power industry? Finally, what is the real impact of financial issue on the wind farms installation?

When you look at the French wind farm installation procedure in ChampagneArdenne, the divergence between the actors' point of view is obvious. The development of wind power is supposed to respect the general European agreement, to produce $23 \%$ of green energy. But, besides the European aspirations and financial aspects, sustainability is never evoked by local authorities, when they are interviewed about the reasons why they want to install a wind farm on their commune and how they operated their decision-making process. The European policy in renewable energy shows the difficulty to change the scale when applied policy, notably with the example of the National Renewable Energy Action Plans (NREAP) (Michalena and Hills 2012).

Moreover, during the local consultation, at the level of the communes, strong individuality usually monopolizes the debate. However, the real power of the communes in deciding over a wind farm is not so important. The real decision level in France is the département, to be more specific the Préfet de départment who is finally the one that delivers (or not) the authorization for building.

The context is very different in other European countries. In Germany, for example, there is a big pressure toward green power anchored in the public opinion and citizens. In Denmark, the production of wind power energy per capita is much bigger than in France, by $20 \%$. And Germans target no fossil energy production by 2050 . Of course, to reach those objectives, those countries follow simpler rules to install wind farms. 


\section{References}

Buclet N (2011) Le territoire entre liberté et durabilité. PUF, Paris

Brunel S (2010) Le développement durable. PUF, Paris

Cettolo H, Lefebre A, Mancebo F (2002) Gouvernance territoriale et pratique culturelle de mobilité: deux exemples de réseaux de tourisme culturel. Département Etudes et Prospectives de la DATAR, Toulouse

Chia E, Torre A, Rey-Valette H (2008/4) Conclusion: vers une «technologie» de la gouvernance territoriale! Plaidoyer pour un programme de recherche sur les instruments et dispositifs de la gouvernance des territoires, vol 209. Norois

Gaudin J-P (2002) Pourquoi la gouvernance? Presses de Sciences Po. coll. La bibliothèque du citoyen, Paris

Hirschman AO (1986) Exit and voice. An expanding sphere of influence. Rivalsviews of market society and otheressays. Harmondsworth, Penguin

Hirschman AO (1970) Exit, voice and loyalty: Responses to decline in firms, organizations and states, Cambridge, M.A., Harvard University Press

Laganier R, Villalba B, ZuindEau B (2002) Le développement durable face au territoire: éléments pour une recherche interdisciplinaire. Développement Durable et Territoire. Dossier $\mathrm{n}^{\circ}$ 1: Approches territoriales du développement durable

Le Galès P (2006) Gouvernement et gouvernance des territoires. Problèmes politiques et sociaux. $n^{\circ} 922$ mars 2006, La Documentation Française Ed., Paris

Le Galès P (1995) Du gouvernement des villes à la gouvernance urbaine. Revue française de Science Politique 45(1):27-95

Mancebo F (2011) Ville durable et changement climatique, environnement urbain/ urbanenvironment, vol 5. VRM, Montréal

Mancebo F (2007a) Le développement durable. Armand Colin, Paris

Mancebo F (2007b) Le développement durable en question(s). Cybergéo, Epistémologie, Histoire de Géographie, Didactique article 404

Michelena E, Hills J (2012) Renewable energy issues and implementation of European energy policy: the missing generation? Energy policy 45:201-216

Mormont M (2001) Gouverner l'environnement, dans DebuysT (F) et al., Savoirs et jeux d'acteurs pour des développements durables, Louvain-la-Neuve, Bruylant-Academia, pp 221-236

Ost F (2004) De la pyramide au réseau: un nouveau paradigme pour la science du Droit? dans SupioT (A), Tisser le lien social (dir.), Paris, Maison de la Science de l'Homme, pp 175-196

Pasquier R Simoulin V WeisbEin J (2007) La gouvernance territoriale. Pratiques, discours et théories. Droit et Société, vol. 44, Paris

Taiclet AF (2007) Le développement économique territorial au regard des hypothèses de la gouvernance territoriale, dans Pasquier R, Simoulin V, Weisbein J (dir.), La gouvernance territoriale. Pratiques, discours et théories, Paris, LGDJ, coll. Droit et Société 44:109-127

Torre A and al (2006) Conflits et tensions autour des usages de l'espace dans les territoires ruraux et périurbains. Le cas de six zones géographiques françaises, Revue d'Economie Régionale et Urbaine ${ }^{\circ} 3: 415-453$ 